NBSIR 78-1549

\title{
Plan for the Assessment and Implementation of Seismic Design Provisions for Buildings
}

Charles G. Culver Robert E. Chapman

Patrick W. Cooke Bruce R. Ellingwood

S. George Fattal James R. Harris Edgar V. Leyendecker

Center for Building Technology National Engineering Laboratory National Bureau of Standards Washington, D.C. 20234

November 1978

Sponsored by:

The National Science Foundation Washington, D.C. 20550 


\section{PLAN FOR THE ASSESSMENT AND IMPLEMENTATION OF SEISMIC DESIGN PROVISIONS FOR BUILDINGS}

Charles G. Culver Robert E. Chapman

Patrick W. Cooke Bruce R. Ellingwood

S. George Fattal James R. Harris

Edgar V. Leyendecker

Center for Building Technology National Engineering Laboratory National Bureau of Standards

Washington, D.C. 20234

November 1978

Sponsored by:

The National Science Foundation

Washington, D.C. 20550

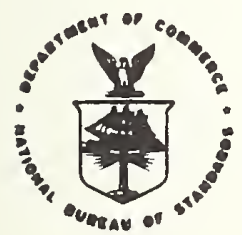

U.S. DEPARTMENT OF COMMERCE, Juanita M. Kreps, Secrotary Dr. Sidnoy Harman, Under Secretary Jordan J. Baruch, Assistant Secretary for Science and Technology NATIONAL BUREAU OF STANDARDS, Ernest Ambler, Director 

This plan deals with the assessment and implementation of tentative seismic design provisions developed by the Applied Technology Council as part of the Cooperative Federal Program in Building Practices for Disaster Mitigation of the National Science Foundation and the National Bureau of Standards. The plan was prepared based on comments received from a broad spectrum of representatives of the building community. The National Bureau of Standards invited participation from a broad spectrum of interests to help develop the plan. Trade associations, industry groups, progessional organizations, the model code organizations, standards organizations and Federal agencies were included; groups with national representation rather than regional or local interest were selected.

The plan includes four phases (1) Review and Refine Tentative Provisions, (2) Trial Designs and Impact Assessment, (3) Consideration and Adoption of Provisions, and (4) Assistance to Facilitate implementation. It can form the basis for the assessment and implementation of the tentative seismic design provisions. As the effort proceeds, it may be necessary to refine the plan. Additional details will need to be specified for the individual tasks. These will be influenced by the procedure adopted to carry out the activities.

Key Words: Assessment; building codes; building design; disaster mitigation; earthquakes; engineering; implementation, standards 


\section{TABLE OF CONTENTS}

PREFACE...................................... 1

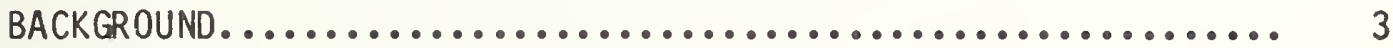

PROGRAM OBJECTIVES................................. 4

GENERAL CONSIDERATIONS......................... 4

ACTIVITIES AND PARTICIPANTS...................... 5

TIME SCHEDULE.................................. 6

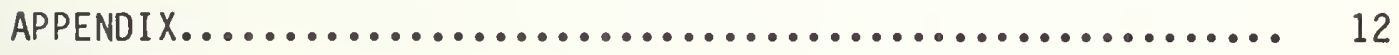



This plan deals with the assessment and implementation of tentative seismic design provisions prepared by the Applied Technology Council as part of the Cooperative Federal Program in Building Practices for Disaster Mitigation of the National Science Foundation and the National Bureau of Standards. The plan was prepared based on comments received from a broad spectrum of representatives of the building community. The National Bureau of Standards invited participation from a broad spectrum of interests to help develop the plan. Trade associations, industry groups, professional organizations, the model code organizations, standards organizations and Federal agencies were included; groups with national representation rather than regional or local interests were selected.

As a first step, a meeting was held at NBS on April 21, 1978, with some 30 invited organizations (Figure 1). A list of the participants is included in the plan. Representatives from forty organizations attended the April 21 meeting and provided their initial views on required elements in the plan. Twenty-nine of these organizations provided additional written comments following the meeting.

The main points raised were:

- Need for consensus agreement on the provisions before adoption for regulatory use.

- Need to evaluate the technical accuracy and correctness of the provisions prior to assessing their economic impact.

- Carry out trial designs involving comparison of the provisions with existing requirements.

- Involve professional and trade organizations directly in assessment activities.

- Provide a mechanism to revise the provisions, if necessary, following the trial designs.

- Provide for continual feedback and response to participant's comments throughout the assessment effort.

Many of the organizations volunteered to participate in carrying out the assessment program.

A first draft plan was prepared by NBS staff based on this material. The draft was forwarded to all participants on July 20 for review and additional comments. Sixteen organizations provided comments. There was general agreement on the overall structure of the assessment effort; the plan reflects this. The comments were used to prepare the final 
plan. Individual responses were provided to each participant indicating how their comments were handled.

This plan can form the basis for the assessment and implementation of the tentative seismic design provisions. As the effort proceeds, it may be necessary to refine the plan. Additional details will need to be specified for the individual tasks. These will be influenced by the procedure adopted to carry out the activities. 
In 1974, the National Science Foundation and the National Bureau of Standards initiated a program to develop improved seismic design provisions for buildings. Damage resulting from the 1971 San Fernando earthquake demonstrated the need for improved provisions. Design professionals, building officials and researchers recommended that model code provisions and a commentary be prepared on a top priority bas is to bring the minimum level of practice in seismic design and construction into line with the state of knowledge.

The NSF/NBS program was carried out working with the Applied Technology Council, a group affiliated with the Structural Engineers Association of California. A multidisciplinary team of some 85 nationally recognized experts in earthquake engineering developed the provisions. During the course of the project, two drafts of the design provisions were prepared for public review by individuals and organizations. In each case approximately 400 copies were distributed for review. The final provisions are included in the report, Tentative Provisions for the Development of Seismic Regulations for Buildings, NBS Special Publication 510, June 1978.

The purpose of the NSF/NBS program was to develop comprehensive seismic design provisions for buildings suitable for use throughout the United States. It was intended that the provisions be available for consideration by model codes and standards organizations and regulatory groups at the Federal, State and local level. As the program evolved, it became clear that a number of issues needed to be addressed prior to adoption of these provisions. These included: (1) determination of the technical viability, consistency and completeness of the tentative provisions, (2) determination of the hazard reduction achieved by the provisions and the associated costs, and (3) evaluation of differences between the provisions and requirements in existing codes and standards. NSF and NBS initiated an effort in 1978 to develop a plan to address these issues. The plan in this report resulted from this work; it defines activities and identifies participants.

The Earthquake Hazards Reduction Act of 1977 (PL 95-124) has as its purpose the establishment of an effective earthquake hazards reduction program. The objectives of the program include, "the development, publication and promotion, in conjunction with State and local officials and professional organizations, of model codes and other means to coordinate information about the seismic risk...." It is anticipated that this assessment and implementation plan will be used in connection with the activities relating to seismic design and construction standards included in the national earthquake hazards reduction program developed in response to the legislation. 
The objectives of the program covered by this plan for the assessment and implementation of seismic design provisions for buildings are to:

1. Refine the technical details of the provisions.

2. Provide a detailed assessment of the viability and impact of the design provisions.

3. Revise the provisions, as necessary, based on results of the assessemnt.

4. Submit the provisions to appropriate groups for adoption.

5. Develop necessary mechanisms to facilitate implementation and enforcement.

\section{GENERAL CONSIDERATIONS}

The National Earthquake Hazards Reduction Program prepared by the President in response to the Earthquake Hazards Reduction act of 1977 recognized the importance of codes and standards in reducing earthquake hazards. The program emphasized non-Federal participation including State and local government, business, industry, the design professions, the research community and the public. The program and the responsibilities defined in the President's plan provide the framework for carrying out the assessment and implemenation effort. The plan also notes that enthusiasm, expertise, and willingness to work are required to make the program effective; contributions in this regard through cost sharing in the commitment of resources involving time and expertise are necessary to carry out the activities of the plan.

The President's plan assigns responsibility for developing seismic design standards for Federal building construction to an Interagency Committee on Seismic Safety in Construction. The committee will be composed of representatives of all Federal agencies significantly engaged in construction, the financing of construction, or related activities. Recognizing that construction undertaken by the private sector is regulated by State and local government, the plan provides for Federal cooperation in developing and improving codes and standards. The National Bureau of Standards is assigned responsibility for the development of seismic design and construction standards for consideration and subsequent application in Federal construction, and the responsibility for encouraging adoption of improved seismic provisions in State and local building codes. NBS, therefore, will serve as the focal point for the assessment effort and will be responsible for overall coordination and management. NBS will also provide technical input and provide the required continuity between the various phases of the work described in subsequent sections of the plan. 
A Codes and Standards Implementation Committee composed of representatives from organizations directly involved in implementing codes and standards will be formed by NBS with the assistance of the Consultative Council of the National Institute of Building Sciences. The Implementation Committee will work directly with NBS providing technical input and comments as the work proceeds, particularly as it relates to final implementation of the provisions. The committee members will also provide direct liaison with their respective organizations. The membership of the committee is given in Figure 2.

The assessment effort will include broad based participation. The Interagency Committee on Seismic Safety in Construction will be involved to insure coordination of work on Federal standards with that for codes and standards for the private sector. Organizations from the private sector will be involved in each phase of the effort. Organizations with particular technical expertise appropriate for each task in the overall program are identified in subsequent sections of this plan. Specific responsibilities and lead roles will be defined through discussions with these organizations as the plan evolves and the assessment effort gets underway.

Recognizing the significant effort involved in developing the provisions included in the report, Tentative Provisions for the Development of Seismic Regulations for Buildings, these provisions and the review comments received on the previous drafts of that report will serve as the basis for the assessment. Where additional research results are available in a form amenable to use in design practice, these will be included, as appropriate, as revisions are made to the provisions. Results from on-going research in earthquake engineering and seismology will be considered in the continuing efforts to develop improved seismic design provisions.

The time schedules for the tasks in the assessment were developed on the basis of initial estimates of the work involved. This schedule relates only to the work involved with the tentative provisions. It does not reflect subsequent efforts to continually improve provisions as new research results become available. Consideration, however, was given to the time schedule established in the President's plan for the other activities related to implementation of the design provisions in codes and standards. Accordingly, results from the assessment effort should be available for consideration as the national program develops.

\section{ACTIVITIES AND PARTICIPANTTS}

The assessment and implementation effort will involve a multi-phase effort. The four phases and the tasks required in each phase are shown in Figure 3. Detailed descriptions of the objectives and activities involved in each Task are included in the Appendix. 


\section{TIME SCHEDULE}

A time schedule for the plan is given in Figure 4 . Where possible, the tasks were scheduled concurrently. In Phase I, for example, all four tasks can be carried on simultaneously. The experimental design in Phase II, Task 1 can be carried on at the same time. Determination of the impacts of the provisions in Task 4 of Phase II can begin prior to completing Task 3 as the data from the trial designs becomes available. 
American Concrete Institute

American Institute of Architects

American Institute of Steel Construction

American Insurance Association

American Iron and Steel Institute

American National Standards Institute

American Plywood Association

American Society of Civil Engineers

American Society of Heating, Refrigerating and Air Conditioning Engineers American Society of Mechanical Engineers

American Society of Plumbing Engineers

Applied Technology Council

Associated General Contractors of America

Association of Engineering Geologists

Association of Major City Building Officials

Brick Institute of America

Building Officials and Code Administrators International, Inc.

Earthquake Engineering Research Institute

International Conference of Building Officials, Inc.

Masonry Institute of America

National Academy of Code Administration

National Concrete Masonry Association

National Conference of States on Building Codes and Standards, Inc.

National Forest Products Association

National Institute of Building Sciences

Portland Cement Association

Post-Tensioning Institute

Prestressed Concrete Institute

Southern Building Code Congress International, Inc.

Structural Engineers Association of California

Federal Agencies

Department of the Air Force

Department of the Army

Department of Energy

Department of Health, Education, and Welfare

Department of Housing and Urban Development

Department of the Navy

Federal Disaster Assistance Administration

General Services Admi nistration

Nuclear Regulatory Commission

U.S. Coast Guard

U.S. Geological Survey

Veterans Administration 
American Concrete Institute

American Institute of Architects

American Institute of Steel Construction

American Institute of Timber Construction

American Insurance Association

American Iron and Steel Institute

American National Standards Institute

American Plywood Association

American Society of Civil Engineers

American Society of Heating, Refrigerating and Air Conditioning Engineers American Society of Mechanical Engineers

American Society of Plumbing Engi neers

Association of Major City Building Officials

Brick Institute of America

Building Officials and Code Administrators International, Inc.

Interagency Committee on Seismic Safety in Construction

International Conference of Building Officials, Inc.

National Concrete Masonry Association

National Conference of States on Building Codes and Standards, Inc.

National Forest Products Association

National Institute of Building Sciences

Portland Cement Association

Southern Building Code Congress International, Inc.

Structural Engineers Association of California 
ASSESSMENT AND IMPLEMENTATION ACTIVITIES

PHASE I - Review and Refine Tentative Provisions

Objective - Resolve questions on technical basis of provisions and refine provisions.

Task 1 - Resolve comments on structural design requirements and design procedures

1 a - Risk Maps

1b - Structural Design

1c - Soil Structure Interaction and Foundations

Task 2 - Resolve comments on materials requirements

$2 a$ - Concrete

$2 b$ - Masonry

$2 c \quad-$ Steel

$2 \mathrm{~d}-$ Wood

Task 3 - Resolve comments on architectural, mechanical and electrical systems and components

Task 4 - Resolve comments on the regulatory use of the provisions

PHASE II - Trial Designs and Impact Assessment

Objective - Establish technical viability of provisions and develop data on economic impact.

Task 1 - Design of Experiment

Task 2 - Trial Designs

Task 3 - Determine Impact

Task 4 - Evaluate Adequacy of Provisions

PHASE III - Consideration and Adoption of Provisions

Objective - Achieve consideration of provisions for adoption by codes and standards organizations.

Task 1 - Adoption by standards organizations

Task 2 - Adoption by model codes 
PHASE IV - Assistance to Facilitate Implementation and Enforcement

Objective - Provide educational training, organizational structure and technical assistance needed for implementation.

Task 1 - Education and Training

Task 2 - Technical Support for Interpretation Services

Task 3 - Develop Guidelines for Evaluation and Inspection

Task 4 - Laboratory Accreditation Criteria

FIGURE 3 - cont. 
Phase I - Review \& Refine Tentative Provisions

Task 1 - Resolve comments on structural design requirements \& design procedures

Task 2 - Resolve comments on materials requirements

Task 3 - Resolve comments on architectural, mechanical \& electrical systems and components

Task 4 - Resolve comments on the regulatory use of the provisions

Phase II - Trial Designs \& Impact Assessment

Task 1 - Design of Experiment

Task 2 - Trial Designs

Task 3 - Determine Impact

Task 4 - Evaluate Adequacy of Provisions

Phase III - Consideration \& Adoption of Provisions

Task 1 - Adoption by standards organizations

Task 2 - Adoption by model codes

Phase IV - Assistance to Facilitate Implementation and Enforcement

Task 1 - Education and Training

Task 2 - Technical Support for Interpretation Services

Task 3 - Develop Guidelines for Evaluation and Inspection

Task 4 - Laboratory Accreditation Criteria

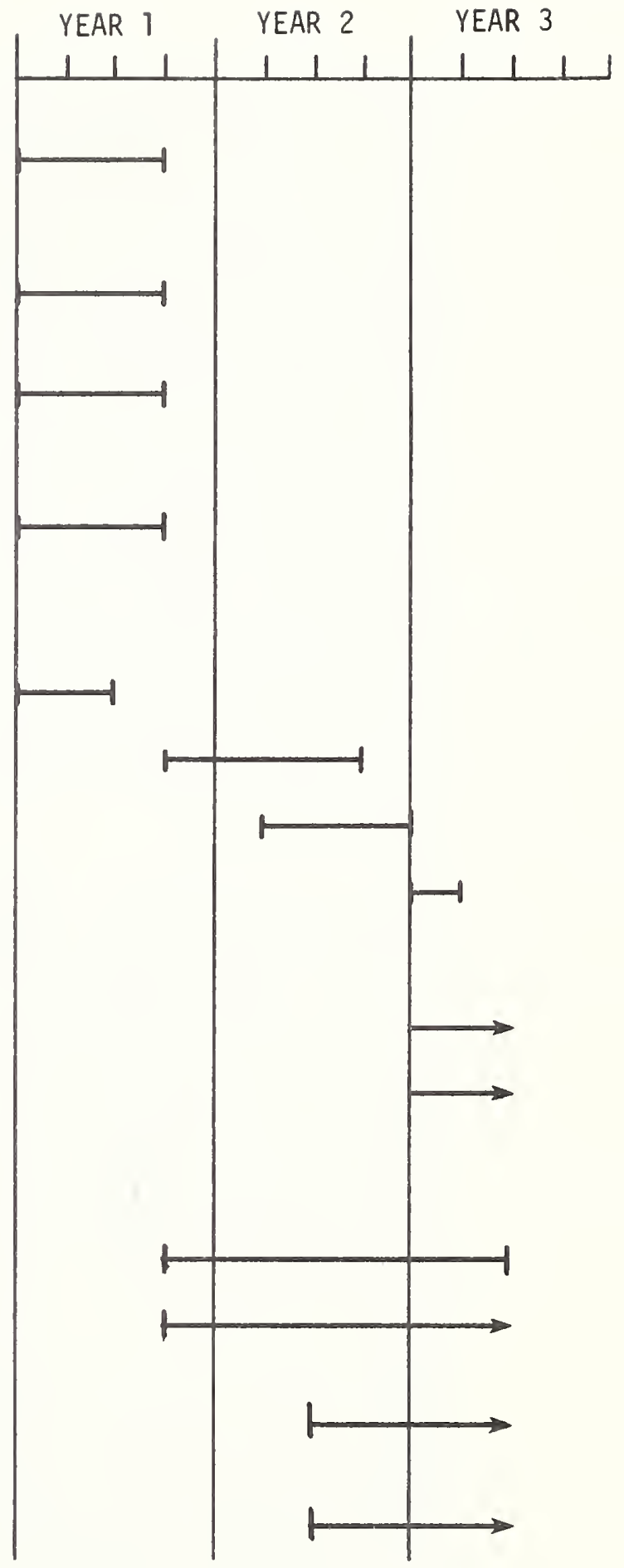


PHASE I - Review and Refine Tentative Provisions

Comments received on the two previous drafts of the tentative provisions from organizations and individuals who were also involved in developing the plan to implement seismic regulations for buildings indicate that differences of opinion exist regarding many of the technical provisions. Many of the provisions appear to be arbitrary and not substantiated by sufficient commentary. Other provisions may not reflect recent research findings fairly. Comments received during development of this plan indicate that these differences of opinion still exist. Particular problems exist in the materials area. The basic design philosophy with respect to the masonry provisions, for example, has been challenged. The importance of reaching consensus on the provisions prior to their adoption has been emphasized by all participants. A number of unresolved issues remain. The objective of the first phase of the assessment is to resolve these issues to the maximum extent possible so that it will be possible to reach consensus agreements in Phase III. Resolution of these issues is the first step toward consensus agreement on the provisions. It is important that these issues be resolved prior to carrying out trial designs in Phase II in order to maximize the benefits from such studies.

The Phase I review will focus primarily on comments received on the two previous drafts of the tentative provisions. The purposes of this review will be: (1) to insure that the trial designs and benefit-cost analysis in Phase II are made with a set of provisions which all affected parties are reasonably satisfied with, and (2) to insure that the provisions are written in enforceable language that can be easily interpreted by designers and code officials. It should be emphasized that Phase I will be limited to an examination and refinement of the existing provisions with possible deletion of some provisions as described subsequently. It is possible that a basic reassessment may take place following Phase II when there will be sufficient design and cost information available to make a reassessment more meaningful.

Committees will be formed from organizations substantially affected by the tentative design provisions. These committees will be invited to review and resolve the comments on the tentative provisions with a representative of ATC. In each case, a positive resolution from the committee concerned with review of a particular provision and comment will be required, i.e., (a) the comment...has merit and the provisions will be changed accordingly, or (b) the comment has been considered and has not been incorporated for the following reason (state reason). Where questions arise regarding the adequacy of the technical bas is of a provision, the ATC representative will provide the basis used in the development of the Tentative Provisions. 
Every attempt will be made to achieve consensus on individual provisions. Where differences of opinion exist regarding the details of a provision and interpretation of the technical data, majority rule will be used to establish the provision to be used in the assessment. Complete agreement obviously will not be possible in every instance. It should be recognized that subsequent tasks in the assessment, particularly Task 2 of Phase II, will provide useful data in this regard. Since these data will affect the final provisions recommended to codes and standards groups in Phase III, complete consensus is not necessary in Phase I. This procedure will assure each affected group that their comments on the provisions definitely have received consideration.

If a majority of the committee members involved in reviewing the particular provision do not concur in the adequacy of the technical basis, and deletion of the provision in question will not disrupt other interrelated provisions, the provision will not be included in the assessment. Should a committee feel that a large portion of the provisions or a provision that is significantly interrelated with others ought to be deleted, it is possible that Phase II would proceed based upon a subset of the original provisions. In any instance, it is probable that Phase II would proceed in order to provide additional information to aid in future resolution of related issues.

This procedure should facilitate the consensus process required for implementation in Phase III. It is anticipated that the Codes and Standards Implementation Committee will provide technical input to this phase. Their early involvement at this stage together with results from the trial designs will provide the background for evaluation of the adequacy of the provisions in Task 4, Phase II.

Phase I will be accomplished through the following four tasks. The organizations involved in each task are listed. It is anticipated that the Applied Technology Council representative will be from the task committee involved in developing the orginal provisions under study by the committee.

Task 1 - Resolve Comments on Structural Design Requirements and Design

This task has three components: seismic risk maps, bases for structural design, and soil-structure interaction and foundations; committees will be formed with responsibility for each component. The committee to evaluate risk maps will consider, among other things, possible variances in the risk maps: the maps which were used as a basis for the current provisions were developed using a new technique which is still being evaluated by seismologists. The committee will include representatives from: 
- American Society of Civil Engineers

- Association of Engineering Geologists

- Interagency Committee on Seismic Safety in Construction

- Seismological Society of America

- Structural Engineers Association of California

- U.S. Geological Survey

- Applied Technology Council

The membership of the committee to evaluate the bases for structural design will consider $R$ and $C_{d}$ factors, strength and deformation criteria, classification of buildings, and analytical procedures, etc. It will include representatives from:

- American National Standards Institute

- American Society of Civil Engineers

- Interagency Committee on Seismic Safety in Construction

- Representation from concrete industry

- Representation from masonry industry

- Representation from prestressed concrete industry

- Representation from steel industry

- Representation from timber industry

- Structural Engineers Association of California

- Applied Technology Council

Each material group will have a representative who will also be involved in Task 2.

The membership of the committee to evaluate the provisions for foundations and soil structure interaction will include:

- American Society of Foundation Engineers

- American Society of Civil Engineers

- Interagency Committee on Seismic Safety in Construction

- Structural Engineers Association of California

- Applied Technology Council

Task 2 - Resolve Comments on Materials Requirements

Four committees will be formed to evaluate the comments received on the provisions that pertain directly to materials. Membership on the group to evaluate the concrete provisons will include representatives from:

- American Concrete Institute

- Portland Cement Association

- Post-Tensioning Institute

- Prestressed Concrete Institute

- Applied Technology Council 
The masonry provisions will be considered by representatives of:

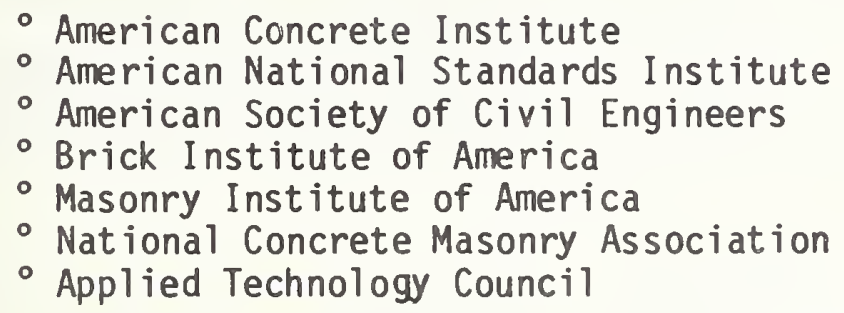

The group to consider the steel provisions will include representatives from:
- American Institute of Steel Construction
- American Iron and Steel Institute
- Metal Building Manufacturers Association
- Applied Technology Council

Provisions for wood structures will be considered by representatives of the following:

- American Plywood Association

- Forest Products Laboratory

- National Forest Products Association

- Applied Technology Council

Task 3 - Resolve Comments on Architectural, Mechanical and Electrical Components and Systems

These provisions will be reviewed by a committee which will include representatives of the following groups:

- American Institute of Architects

- American Society of Heating, Refrigerating and Air Conditioning Engineers

- American Society of Mechanical Engineers

- American Society of Plumbing Engineers

- Interagency Committee on Seismic Safety in Construction

- National Elevator Industry, Inc.

- National Fire Protection Association

- Applied Technology Council

There is a paucity of information regarding the performance of mechanical and electrical systems during earthquakes. Nevertheless, damage to these systems is a major source of earthquake damage. Concern has been expressed that satisfaction of certain provisions is not possible with existing technology. Other provisions impose burdens of certification of equipment upon manufacturers that may be impractical and incompatible with present manufacturing processes. Particular attention will be paid during the review to the practicality of the provisions for mechanical and electrical equipment. 
Task 4 - Resolve Comments on the Regulatory Use of the Provisions

The purpose of this task is to review the provisions for enforceability and ease of interpretation by designers and building officials. The membership of the committee to carry out this task will include representatives of the following organizations:

- American Insurance Association

- Associated General Contractors of America

- Assocation of Major City Building Officials

- Building Officials and Code Administrators International

- Building Owners and Managers Association

- Construction Research Council

- International Association of Plumbing and Mechanical Officials

- International Conference of Building Officials

- National Conference of States on Building Codes and Standards, Inc.

- Southern Building Code Congress International

- Applied Technology Council

The comments to be resolved include:

(1) Comments on the administrative requirements and procedures established, particularly in Chapters 1 and 13, and

(2) Comments about the enforceability of the technical provisions.

Representatives of the model code organizations have made particularly strong comments about Chapter 13, "Systematic Abatement of Seismic Hazards in Existing Buildings." It is not expected that the question of the feasibility of code adoption of such a large scale retroactive program would be resolved by this committee. The focus of this task committee is to resolve questions of wording, procedures, and clarity, not organization, programs or philosophy.

The tasks involved in Phase I cannot be carried out independently; interaction between the committees is required. Determination of the seismic force levels involved in Task 1 and the materials performance in Task 2 are an integral part of good design. Similarly, practicing professionals (architects and engineers) will need to be consulted in Task 4. The four tasks will therefore be closely coordinated by NBS.

It is anticipated that the four tasks in Phase I can be completed simultaneously in 6 months from the start of the project.

PHASE II - Trial Designs and Impact Assessment

This phase of the plan focuses on establishing a viable framework for carrying out trial designs and for interpreting and assessing their economic impacts on the construction industry and the general public. 
The scope of this phase will be limited to the provisions dealing with new construction. It has as its technical base the revised set of seismic design provisions resulting from the Phase I effort. Engineering expertise, economic theory and statistical methods will be utilized in order to maximize the content and quality of the information produced in the trial design case studies.

The basic objective of this phase is to establish the technical viability of the provisions and to develop and analyze data on the economic impacts of the seismic design provisions. In addition, this phase will facilitate the revision of specific provisions which may be too stringent or too lax. As such, it will permit the requirements of the Earthquake Hazards Reduction Act of 1977 (PL95-124) to be met in the most cost-effective way.

\section{Task 1 - Design of Experiment}

The experiment of conducting trial design must be carefully designed to assure that the results can be extrapolated reliably beyond the specific examples in order to evalute the technical and economic implications of the seismic design provisions. Given practical limits on funding, only a limited number of trial designs can be conducted, so special consideration must be given to the way in which sites and building types are selected. Ideally, construction market information should be collected and statistical methods utilized to insure that the trial designs provide the data needed to determine measures of the impacts of the provisions. In particular, the two following criteria should be satisfied:

(1) Those cities selected for the trial designs (which might be hypothetical average cities) should be representative of the variations in seismic risk across the United States and

(2) Those building types analyzed should represent the type of new construction most likely to be substantially affected by the new seismic provisons.

Several factors appear to be of importance in selecting the candidate sites. These factors are:

(1) Seismic risk

(2) Population density

(3) Number of existing buildings

(4) Value of new construction, and

(5) Presence or lack of existing seismic provisions in building codes

Careful consideration must be given to the availability of data which would facilitate the extropolation of cost studies from individual buildings to the entire construction market. This would include effects 
on the labor and materials markets. (Exarnples of such information would be input-output or econometric models.) Consideration should also be given to the availability of data on benefits expected to accrue as a result of improved seismic resistant design.

Criteria which are useful in identifying candidate building types include:
(1) Size (area and height)
(2) Use (occupancy)
(3) Configuration
(4) Structural materials and systems
(5) Foundation materials and systems
(6) Non-structural walls and partitions, and
(7) Mechanical and electrical equipment and systems (particularly their supports and attachments).

The National Bureau of Standards with input from the Codes and Standards Implementation Committee, should be responsible for designing the experiment, specifying where and how many trial designs are to be carried out, and insuring that the results of the trial design task provide the material necessary to assess the impacts of the seismic design provisions. It is estimated that the experimental design can be completed within six months.

\section{Task 2 - Trial Designs}

The objective of this task is to develop, through trial designs of representative buildings, a quantitative basis for evaluating the practical impact of the tentative provisions, together with the revisions and refinements introduced in Phase I.

The three major activities envisioned for this task are:

(1) Planning and coordination of work

(2) Conduct the trial designs, and

(3) Collection of cost information

Planning and coordination will involve selection of consulting firms, drafting the work statements based on Task 1, letting the actual contracts, and assuming supervisory and monitoring responsibilities until completion of contractual obligations. Organizations with the potential for planning and coordinating this work include: American Society of Civil Engineers, American Institute of Architects, National Society of Professional Engineers, American Consulting Engineers Council, and the National Bureau of Standards. The Applied Technology Council will provide interpretation of the provisions during conduct of the trial designs. 
The consultant will prepare two designs for the same structure. One of the designs will be in accordance with the ATC 3 provisions as modified in Phase I. The other design will be based on existing building regulations as identified in Task 1. In addition, the consultant will supply comparative data between the two designs, including a quantitative estimate of the differences in design costs and an itemized list comparing the substantive differences between the two sets of provisions. It is possible that Task 1 will specify that the consultant will also supply construction cost estimates. If so, the consultant will be asked to provide comparative cost estimates of construction on the bas is of actual bids for the job obtained from several contractors. In order to control variations in estimated construction costs and materials usage among the consultants developing the trial designs, a single cost accounting firm will prepare detailed sets of comparative construction cost estimates. Construction inspection costs will also be estimated. Costs estimates will also be obtained for plan review and inspection in the enforcement by building code officials.

The information acquired from the trial designs will be consolidated and used as a basis to determine the impact of the seismic provisions on the building community (subsequent Task 3 ) and to assist in the decision making process (subsequent Task 4).

It is estimated that the task of trial designs can be completed 12 months after initiation. It can commence at 8 months into Year 1.

Task 3 - Determine Impacts

The determination of the impacts associated with the seismic design provisions developed in Phase I are threefold. The first level of analysis relates to the impact on costs for a given building in a given location. The second level of analysis refers to the impact that the use of the seismic design provisions has on the construction industry. The second level is more complicated than the first because individual impacts may vary with building type, location, and/or current seismic codes. The extrapolation from the trial designs to the impacts on cities, regions and the nation becomes increasingly more difficult. Certain elements of the construction industry or certain geographic areas may be more strongly affected than others. These impacts represent a real cost which cannot be ignored and which must be carefully weighed against any benefits to society or to competitors. The third level of analys is relates to any changes in benefits and costs which accrue to society as a result of the seismic design provisions. A description of each level of analysis and its impacts is summarized below.

Level 1

Two sets of cost calculations will be available as a result of the trial design case studies. Using this information, the comparative impact of the seismic design provisions in each of the following areas will be determined: 
(1) Initial capital cost of the project

(2) Type and amount of building materials

(3) Type and amount of labor

(4) Physical characteristics of the building

(5) Insurance costs, and

(6) Regulatory costs

Level 2

The results from the level 1 analysis will produce a set of micro impacts on the construction industry. To see how all of these micro impacts will affect the construction industry, it will be necessary to divide the industry into sectors and the nation into regions. The sectors which are of particular importance and which will be examined in detail are:

(1) Building materials producers

(2) Building materials suppliers

(3) Building equipment suppliers

(4) Building regulatory authorities

(5) Architectural/Engineering design firms, and

(6) Labor

Level 3

In level 3, as detailed a benefit-cost analysis as possible will be performed. The results of the benefit-cost analysis will indicate if society is better or worse off by going to an increased level of seismic safety outlined in the seismic design provisions. The costs of the seismic design provisions will be based on detailed summaries of the results of the first two levels of analysis. Economic criteria and published statistics will then be used to estimate those benefits accruing to society from the use of the seismic design provisions. Particular emphasis will be placed on estimating deaths and injuries and property damages averted. If related benefits or costs which might accrue to building owners, occupants, or society in general, due to use of these provisions can be identified, they will be considered.

Once societal benefits have been estimated, it will then be necessary to examine how these benefits are distributed over individual buildings. This approach should point out whether or not the seismic design provisions are economically efficient from a benefit-cost viewpoint for a particular building type. This approach should also facilitate the identification of specific provisions, if any, which are likely candidates for revision.

The National Bureau of Standards with input from the implementation committee will be responsible for this task. Nationally recognized management consulting firms will participate with NBS in this activity. Nine months will be required for this task. 
Task 4 - Evaluate Adequacy of Provisions

This task is an evaluation of the results of the economic impact study based on the refined provisions determined in Phase I. The purpose of the evaluation is to determine if additional refinements are necessary prior to proceeding to the implementation of Phase III. Three basic outcomes are considered possible. The first of these is to proceed directly to Phase III. The second is that additional refinement of the provisions is required in order to lessen the economic impact. This will require repeating Phases I and II although on a much smaller scale than the original phases. The third option is a complete reassessment of the seismic design provisions.

Responsibility for this evaluation should rest with the Codes and Standards Implementation Committee. This committee should establish criteria for determining the adequacy of the provisions and develop procedures for evaluating the provisions based on the assessment data obtained.

PHASE III - Consideration and Adoption of Improved Provisions For Seismic Resistant Design

The objective of this phase is to achieve adoption of the provisions in national standards and model codes. It is important that this activity be carried out in a coordinated fashion. There are several factors to consider in achieving suitable coordination. There are two tasks in this phase:

- Task 1 - Adoption of the provisions by national standards organizations

- Task 2 - Adoption of the provisions by model codes organizations

These two tasks will be discussed simultaneously.

It is apparent that the new seismic provisions impinge upon a large number of standards. Thus, the activities of many different organizations must be coordinated in order to achieve the objective. The work of Phase III will be carried out by the implementation committee. For these tasks the committee assumes the additional role of carrying out the work. Note that the implementation committee does not include representation from city and State building code authorities. Although the entire objective of PL 95-124, with regard to buildings, hinges upon achieving improved provisions in legal codes, this plan does not include the coordination of activities at that level. There are several reasons for this: the scale of this plan is necessarily national, and once developed, the local activities will follow; changes in local codes normally follow changes in model codes; there are 
so many different local codes that the national standards and model codes interests on the advisory committee would be overwhelmed; and there are several organizations included that effectively represent local interests.

The activities can be separated into four functions:

(1) Planning and scheduling their activities (with respect to the provisions) around those of each standard and code organization. This could feasibly include recommending the creation of a new standard where none exists.

(2) Placing the appropriate new provisions on the agenda of each individual organization and advocating their consideration.

(3) Reporting back to the entire committee on what actions each organization is taking with regard to the new provisions.

(4) Consideration of and decision on what new actions are to be taken (if any) as a result of rejection or modification of the new provisions by any organization.

There are two priorties that the implementation committee would be expected to observe in planning and scheduling their activities. First, it would be expected that the new provisions be considered by national standards before they are considered by the model codes. The rationale behind this is that many of the national standards arrive at decisions in accordance with the rules of ANSI governing voluntary consensus standards for balanced representation among committee membership, due process for notification, balloting and resolution of dissent, and for definition of substantial agreement, whereas none of the model code organizations follow the complete set of ANSI rules.

The second priority for scheduling is that among the standards for structural design, ANSI A 58 should lead and the several standards for the design of concrete, steel, masonry, and wood structures should follow. It is clear that there is only one significant standard for the loads for which structures are to be designed and that there are several for determining the strength and stiffness of buildings and components and for the detailed rules of construction, each peculiar to a specific building material. Thus, if $A 58$ reáches a decision first, then all the materials standards, will be assured of a common basis of reference for loads. In addition, A 58 is structured to achieve consensus according to ANSI, whereas several of the materials standards are not.

The fourth activity listed in this phase, that of deciding on new actions to take as a result of unilateral rejection or modification of the new provisions by any organization is important because of the nature of the provisions developed by ATC. The consideration of 
inelastic behavior in resisting seismic loads requires that provisions for the effect of load on a structure and the strength and stiffness of that structure be coordinated in a fashion that philosophies of elastic design have not required. For this reason actions of individual standards organizations cannot be viewed as independent activities, and it may be necessary for the implementation committee to recommend revised provisions, or the development of revised provisions, to one organization as the result of the action of another organization.

PHASE IV - Assistance to Facilitate Implementation And Enforcement

This phase of the plan recognizes the burden the provisions will place on the building regulatory process as well as the design professionals and other members of the building community. It provides for information and technical assistance to the States and other jurisdictions in the adoption, implementation and ongoing enforcement of the seismic design provisions. Also, the emphasis of the standards has been towards a broader performance orientation. Performance standards have the desired effect of providing for end results without specifying the material, component or system thus allowing maximum freedom to provide innovative solutions. However, to the extent that the standards are performance oriented, they further increase the complexity of interpretation, evaluation and enforcement for both design professionals and regulatory officials. The proposed tasks outlined in this phase are designed to facilitate the effective implementation of the standards in a coordinated manner.

The primary objectives of this phase of the plan will be to provide the necessary education and training, organizational structure and technical and professional assistance, so that buildings can be successfully designed and evaluated in compliance with the standards. In addition, a secondary objective will be to track the implementation progress by States and local regulatory agencies and to assess the methodology and completeness of State or local implementation.

Task 1-Education and Training

It will be necessary to educate and train members of the building community for successful implementation of the seismic design provisions.

The training project will plan, develop and deliver training courses for design professionals, builders, building regulatory officials, industry representatives and other interested members of the building community. Training materials and prototype courses will be developed for the varied segments of the building community and instructors will be selected, trained and certified. Pilot sessions will be conducted to judge the adequacy of course materials for each course of training. Instruction will be carried out in numerous locations. The following organizations may be expected to play a role in this task: 
- American Society of Civil Engineers

- American Institute of Architects

- American Society of Mechanical Engineers

- American Society of Heating, Refrigeration and Air Conditioning Engi neers

- Building Officials and Code Adminstrators International

- International Conference of Building Officials

- National Society of Professional Engineers

- National Conference of States on Building Codes and Standards, Inc.

- National Academy of Code Admi nistration

- Southern Building Code Congress International.

Other professional organizations including regional organizations such as the Structural Engineers Association of California are expected to play an important role in this task. Materials organizations should also contribute to the development and dissemination of educational information.

\section{Task 2 - Technical Support for Interpretation Services}

Implementation of the seismic design provisions will generate many questions from the building regulatory community concerning interpretation of its provisions. In some cases it will be necessary to provide technical support for the interpretation services of existing standards organizations when questions arise which are not of a routine nature.

Questions of a technical nature on the seismic design provisions will arise which cannot be routinely answered with the existing level of knowledge among code compliance officials and building officials. In such cases, research projects may be identified which could respond to the technical need within the limited time constraints. Additional types of technical support could include testifying before building codes and standards generating groups, holding seminars on technical issues resulting from implementation of the provisions and routine distribution of research findings. The Applied Technology Council and National Bureau of Standards are both expected to play a meaningful role.

Task 3 - Develop Guidelines for Evaluation and Inspection

Implementation of the new seismic design provisions by State and local regulatory authorities will be aided considerably by model documents relating to the following:

(a) Test data and information to be submitted to agencies by producers

(b) Evaluation procedures, techniques, guides and reports to be utilized 
(c) Approval reports to be issued by agencies

(d) Inspection procedures, techniques, and certification systems to assure compliance to the standards

(e) Data and information to be submitted to local enforcement agencies pertaining to construction, installation and/or occupancy.

The required manuals for use of building inspectors and evaluators will be developed in consultation with the building industry, regulatory agencies, and other segments of the building community. Every attempt will be made to make the manual easy to use under field conditions by regulatory officials at the inspector/evaluator level. Pilot field testing of the manuals and resulting modifications will precede distribution and use on a national level. The development of such a system will consider and be based in part on existing regulatory programs and evaluation/approval systems. The approach to be used will be based on earlier NBS-developed Coordinated Evaluation System (CES) type models.

The following organizations have traditionally provided services of this type:

- National Bureau of Standards

- National Conference of States on Building Codes and Standards, Inc.

- Association of Major City Building Officials

- International Conference of Building Officials

- Building Officials and Code Administrators International

- Southern Building Code Congress International

- Structural Engineers Association of California

Task 4 - Laboratory Accreditation Criteria

This activity has as its objective the provision of a supporting base of accredited testing and evaluation agencies required for implementing the new seismic design provisions. This is particularly important in the areas of electrical, mechanical and plumbing systems. It includes the employment of associated ASTM Standards to evaluate and accredit agencies to perform the new evaluation tasks that will be required and laboratories to perform physical testing and rompliance assurance functions required by reguldtory authorities. This task will also define and dssist in the establishment of the intrastate and interstate laboratory accreditations that will enable reciprocal exchange of creditable certifications and approvals of building components, equipment and designs.

Work wi 11 be coordinated with the National Voluntary Laboratory Accreditation Program of the Department of Commerce and the established ASTM standards committees (E-32 and E-36). It may be necessary to expand coverage of existing standards relating to laboratory accreditation. Development of necessary standardized test methods will be included in this task. 
The organizations that will be involved in this activity are:

- American Society for Testing and Materials

- National Bureau of Standards.

The schedule for carrying out the tasks of Phase IV suggests that Task 1 should be inititated shortly after the completion of Phase I and be continued beyond the duration of adoption by regulatory authorities.

Task 2 would not be initiated until the adoption of Phase III has begun. Duration would be indefinite.

Tasks 3 and 4 could both begin in the second year concurrent with the later stages of Phase II and continue for a period of two years. 
NBS.114A (REV. 11.77)

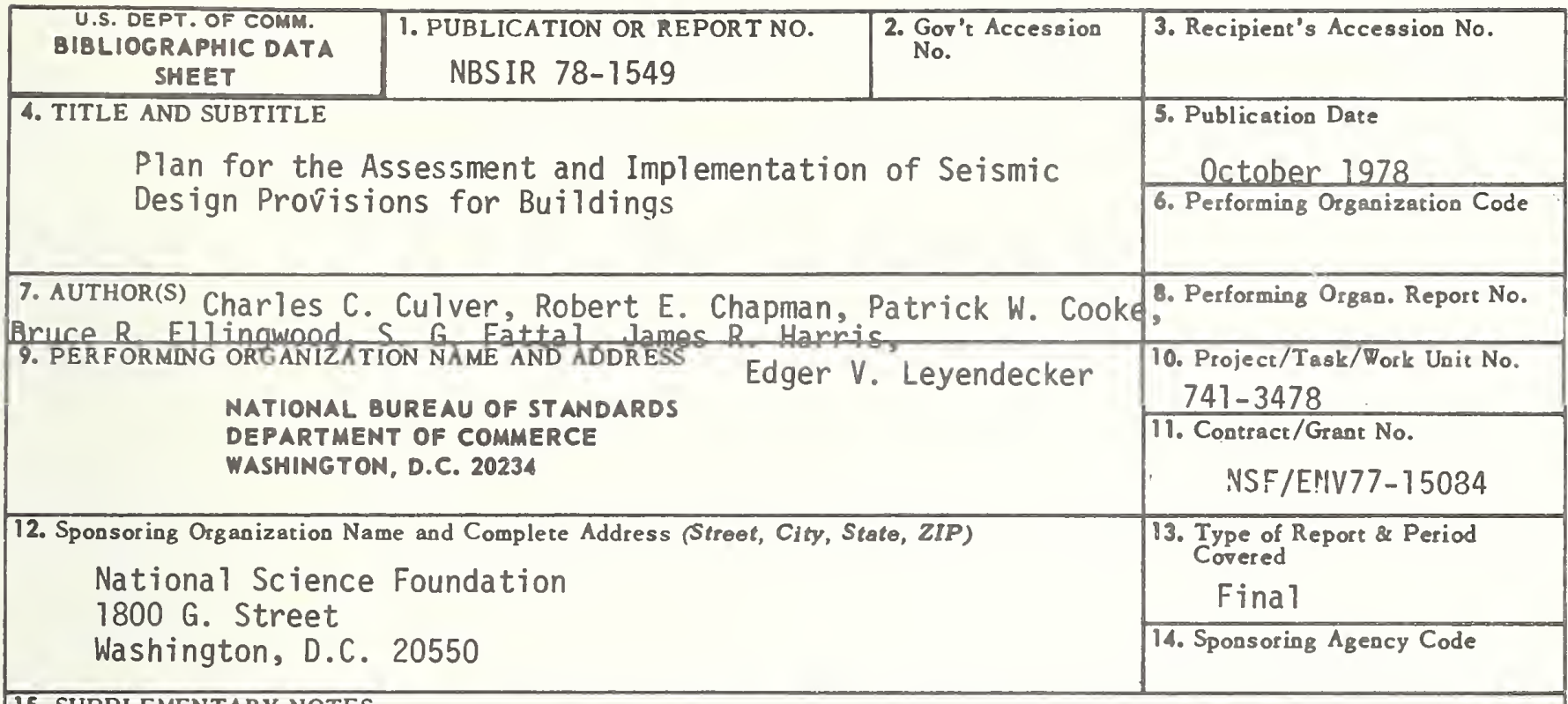

15. SUPPLEMENTARY NOTES

16. ABSTRACT (A 200-word or less factual summary of most significant thformation. If document includes alenificant bibliography or literature survey, mention it here.)

This plan deals with the assessment and implementation of tentative seismic design provisions developed by the Applied Technology Council as part of the Cooperative Federal Program in Building Practices for Disaster Mitigation of the National Science Foundation and the National Bureau of Standards. The plan was prepared based on comments received from a broad spectrum of representatives of the building community. The National Bureau of Standards invited participation from a broad spectrum of interests to help develop the plan. Trade associations, industry group, professional organizations, the model code organizations, standards organizations and Federal agencies were included; groups with hational representation rather than regional or local interest were selected.

The plan includes four phases (1) Review and Refine Tentative Provisions, (2) Trial Designs and Impact Assessment, (3) Consideration and Adoption of Provisions, and (4) Assistance to Facilitate implementation. It can form the basis for the assessment and implementation of the tentative seismic design provisions. As the effort proceeds, it may be necessary to refine the plan. Additional details will need to be specified for the individual tasks. These will be influenced by the procedure adopted to carry out the activities.

17. KEY WORDS (six to twolve entries; alphabotical order; capitalize only the firat letter of the firat key word unlese a proper name; separated by semicolona)

Assessment; buildina codes; building design; disaster mitigation; earthquakes; engineering; implementation; standards.

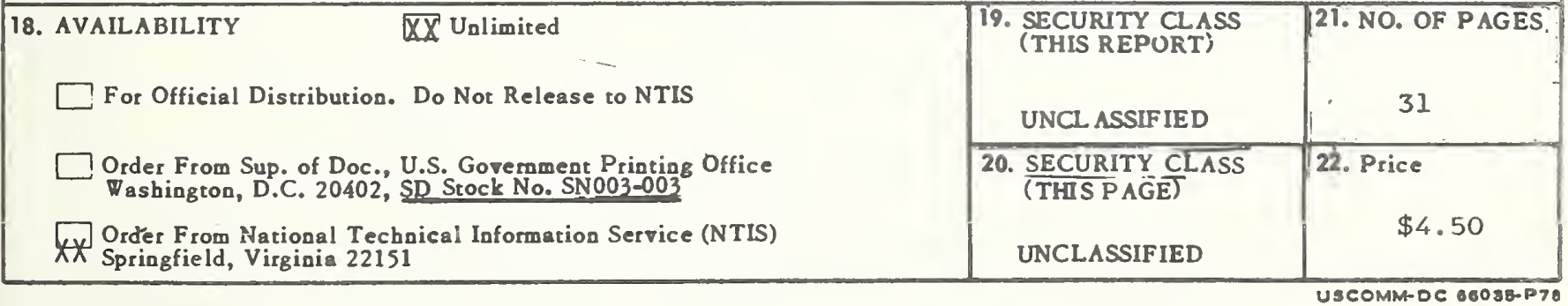



